\title{
Anaerobic Process for Biohydrogen Production using Keratin Degraded Effluent
}

\author{
Gujuluva Hari Dinesh ${ }^{1,2}$ D, Ramu Satheesh Murugan ${ }^{1,2}$, Kulanthaisamy \\ Mohanrasu $^{1,2}(\mathbb{D})$, Nagarajan Arumugam ${ }^{3}$ (D) Muthuramalingam Jothi Basu ${ }^{4}$ and \\ Alagarsamy Arun ${ }^{2 *}$ iD
}

${ }^{1}$ Department of Energy Science, Alagappa University, Karaikudi - 630 003, India. ${ }^{2}$ Department of Microbiology, Alagappa University, Karaikudi - 630003 , India. ${ }^{3}$ Department of Biotechnology, Indian Institute of Technology Madras, Chennai - 600 036, India. ${ }^{4}$ Department of Botany, Alagappa University, Karaikudi - 630 003, Tamilnadu, India.

\begin{abstract}
Fossil fuel energy depletion and removal of environmental wastes are big problem in many countries. Some of the wastes contain a considerable amount of protein and carbon compounds; little concentration is given to utilizing or recycling these wastes in a technological way for production of renewable energy. Feathers are generated in large amounts as waste at commercial poultry processing plant, reaching millions of tons per year worldwide. Feathers are rich in keratin protein. In this work, keratin was degraded and the degraded effluent was evaluated for biohydrogen production by anaerobic (dark fermentation) process. The keratin degrading microorganisms were isolated from the soil sample where the feather wastes were disposed using minimal media with prepared keratin powder. The isolates were named as KHAD1, KHAD2 and KHAD3. The isolates were identified as Serratia marcescens KHAD1 (MH422128), Bacillus subtilis KHAD2 (MH422129) and Pseudomonas aeruginosa KHAD3 (MH422009) based on their $16 \mathrm{~S}$ rRNA sequencing. The isolates were screened for biodegradability of keratin protein and higher biodegrading potential microorganism such as Pseudomonas aeruginosa KHAD3. The optimization studies for biohydrogen production using isolates in keratin degraded effluent at various $\mathrm{pH}(1,2,4,6,8,10 \& 11)$. The maximum biohydrogen production was obtained at $\mathrm{pH} 11(210 \mathrm{ml} / \mathrm{L})$ by Pseudomonas aeruginosa KHAD3.
\end{abstract}

Keywords: Biohydrogen, Keratin biodegradation, poultry waste, chicken feather, Dark fermentation.

\footnotetext{
*Correspondence: arunalacha@gmail.com

(Received: 15 January; accepted: 26 March 2019)
}

Citation: Gujuluva Hari Dinesh, Ramu Satheesh Murugan, Kulanthaisamy Mohanrasu, Nagarajan Arumugam, Muthuramalingam Jothi Basu and Alagarsamy Arun, Anaerobic Process for Biohydrogen Production using Keratin Degraded Effluent, J Pure Appl Microbiol., 2019; 13(2): 1135-1143. doi: 10.22207/JPAM.13.2.52

(C) The Author(s) 2019. Open Access. This article is distributed under the terms of the Creative Commons Attribution 4.0 International License which permits unrestricted use, sharing, distribution, and reproduction in any medium, provided you give appropriate credit to the original author(s) and the source, provide a link to the Creative Commons license, and indicate if changes were made. 


\section{INTRODUCTION}

A large proportion of world energy needs are being covered by fossil fuels, which have led to an accelerated consumption of non renewable resources ${ }^{1}$.

As the world population started to grow, mankind started for searching more effective means of energy production, turning towards the use of coal, oil and an even more energy efficient fossil fuel. Consequently the use of fossil fuels in order to cover the continuously increasing energy demands has resulted to the excessive accumulation of carbon dioxide bringing humanity to an imminent world energy crisis ${ }^{2}$. The rapid depletion of fossil resources which is considered the main cause of global warming.

Nowadays, over exploitation of fossil fuels has brought mankind to a dead end from both an environmental and energy resource standpoint. Fossil fuels used as a major energy source for decades, caused undesirable emissions to the atmosphere leading serious air pollution problems. The indiscriminate use of fossil fuels and consumption of non renewable resources drive the current economy towards alternative energy sources. Considering global environmental impacts, such as green-house effect and resource recovery, there is a pressing need to develop nonpolluting and renewable energy source $e^{3-5}$.

Hydrogen is the most promising alternative energy as it has a high energy yield of $142.35 \mathrm{KJ} / \mathrm{g}$ and high energy density of 122 $\mathrm{KJ} / \mathrm{g}$. It is the most abundant element which is clean, renewable fuel because the product of its combustion is only pure water and generates zero emissions when burned for energy recovery ${ }^{6}$.

Hydrogen is safer to handle than domestic natural gas. Hydrogen is now universally accepted as an environmentally safe, renewable energy resources and an ideal alternative to fossil fuels that does not contribute to the greenhouse. Presently, $40 \%$ hydrogen is produced from natural gas $30 \%$ from heavy oils and naphtha, $18 \%$ from coal and $4 \%$ from electrolysis and about $1 \%$ is produced from biomass. However, today, biological hydrogen production processes are becoming important mainly due to two reasons; utilization of renewable energy resources and usually operated at ambient temperature and atmospheric pressure ${ }^{7}$.
Biologically produced hydrogen is a valuable gas which is seen as a future energy carrier and therefore demand for hydrogen has increased considerably in recent years. Biological production of hydrogen provides a feasible means for the sustainable supply of hydrogen with low pollution and high efficiency, thereby being considered a promising way of producing hydrogen. Hydrogen production via biological routes provides a cost-effective and pollution free alternative to conventional thermal/chemical conversion of fossil fuels into hydrogen ${ }^{8}$. Biotechnology of hydrogen production has aroused a broad attention around the world as an environmentally friendly process.

Environmental wastes are found in large quantities in many countries. Although some of them contain a considerable amount of protein and various carbon compounds, little attention is given to utilizing or recycling these wastes in a technological way. Feathers are generated in large amounts as waste byproducts at commercial poultry processing plant, reaching millions of tons per year worldwide. Feathers are rich in keratin protein; keratins are stable, insoluble structural proteins found in the epidermis of vertebrates, its appendages such as feathers and hair. The ב-helix or $\lambda$-sheet keratin chains are tightly packed into a supercoiled polypeptide chain extensively crosslinked with disulphide bridges, hydrogen bonds and hydrophobic interactions, resulting in the mechanical stability of keratin and its recalcitrance to common proteolytic enzymes such as pepsin, trypsin and papain?

However, despite its recalcitrance, keratin can be efficiently hydrolysed by keratinolytic enzymes produced by a multitude of bacteria and fungi and particularly representatives of the bacterial genus Bacillus appear as prominent keratinolytic micro-organisms ${ }^{10}$. Bacterial keratinolytic proteases show a potential to be utilized for feather bioconversion, enhancement of enzyme activities and increase in yields are required to make these suitable for industrial applications. Since feathers are almost pure keratin protein, feather wastes represent a potential alternative to more expensive dietary ingredients for animal feedstuffs. They require physical and chemical treatments to destroy certain aminoacids ${ }^{11}$. Therefore, biodegradation of feather keratin by microorganisms represent an alternative 
method to improve the nutritional value of feather waste and to prevent environmental contamination.

Keratinolytic activity assays and soluble protein determination using insoluble keratin or feather powder and culture supernatants was determined. Production of extracellular proteases by Bacillus sp. during growth on feather broth was evaluated by zymograms analysis. The keratin degraded effluent was analyzed for biohydrogen production as the effluent contains both the culture and degraded feathers. The present study was carried out to investigate the use of degraded feather waste for the biohydrogen production.

\section{MATERIALS AND METHODS \\ Preparation of keratin substrate}

Chicken feathers were collected from commercial poultry farm, Madurai. The feathers were washed thoroughly with water to remove the debris and then sundried for 3 days. The barbules present in the feathers were removed manually and oven dried at $75^{\circ} \mathrm{C}$ for 8 hours. After oven dried, the keratin materials were chopped into pieces and then milled using mixture grinder to obtain an approximate mesh particle size of $6 \mathrm{~mm}$. The powder was used for further study.

\section{Isolation and Identification of keratin degrading} microorganisms

Keratin degrading microorganisms were isolated from the soil sample where the feather wastes were disposed. The soil sample was collected in sterile dark polythene bag and was transported to the laboratory. One gram of the soil was added to $9 \mathrm{ml}$ of sterile saline blank and was serially diluted up to $10^{-9}$ dilution. $0.2 \mathrm{ml}$ of the serially diluted samples was aseptically plated on minimal media containing keratin powder as a substrate. The plates were incubated at $37^{\circ} \mathrm{C}$ for 3 days $^{12}$.

The protein utilizing capability of the isolates was screened by growing on skim milk agar medium. The morphologically different microorganisms observed on minimal media containing keratin as substrate were individually streak plated on sterile skim milk agar medium plates. The plates were incubated at $37^{\circ} \mathrm{C}$ for 24 $h$ and were observed for the clear zone around the colonies. The maximum clear zone producing organism was used for bacterial identification studies.

The selected pure isolates were identified based on their microscopic, morpho-logical, biochemical characters ${ }^{13}$ and partial sequencing of their 16S rRNA. The isolation of DNA was done according to Janardhanan and Vincent ${ }^{14}$. The partial 16S rRNA was amplified according to Rochelle et al. ${ }^{15}$. Partial DNA obtained from PCR was sent for sequencing service. The sequences of the partial 16S rRNA were compared with the 16S rRNA sequence available in the public nucleotide databases at the National Center for Biotechnology Information (NCBI) by using its World Wide Web site (http://www.ncbi.nlm.nih.gov) and the BLAST (basic local alignment search tool) algorithm.

\section{Degradation of keratin waste and Biohydrogen} production

The Biodegradation of keratin waste and chicken feather by using the isolates was carried out as referred by Shawkey et al. ${ }^{16}$. The submerged cultivation using the isolates was performed on feather broth with Keratin powder or chicken feather as substrate. The chicken feather to be used in the experiment was washed with $0.1 \%$ Triton X100 and further washed with distilled water.

Sterile $50 \mathrm{ml}$ of feather broth containing keratin powder or chicken feather with different $\mathrm{pH}(1,2,4,6,8,10$ and 11) was prepared and were aseptically inoculated with keratin degrading bacterial isolate.

To differentiate the level of keratin biodegradation, instead of using feather broth, minimal media ${ }^{12}$ was used. One set of inoculated samples were incubated at $30^{\circ} \mathrm{C}$ in shaker for 7 days. Another set of inoculated samples were sealed with aluminum cap and nitrogen gas were sparged for 5 minutes and were incubated at room temperature for 7 days. After incubation, the samples were used for the analysis of biohydrogen, keratin biodegradation (weight loss\%), physical and chemical Characterization ( $\mathrm{pH}, \mathrm{ORP}$, Alkalinity, VFA, COD, BOD, Protein \& Glucose).

\section{Analysis of hydrogen production}

At regular intervals, the gas produced in the headspace was analyzed using sterile glass syringe. The biohydrogen produced in regular intervals was expressed in $\mathrm{ml}$.

Cumulative hydrogen production $(\mathrm{ml} / \mathrm{l})$ was obtained by using modified Gompertz 
equation (Eq.1) $)^{17,18}$; the Volumetric Hydrogen production rate (HPR) $\left(\mathrm{ml} \mathrm{l}^{-1} \mathrm{~h}^{-1}\right)$ was calculated from cumulative hydrogen production $(\mathrm{ml} / \mathrm{l})$ divided by fermentation time (h). Hydrogen yield (HY) (mmol/mol glucose) was calculated as total molar amount of hydrogen divided by molaric amount of consumed glucose (as reducing sugar). The total molaric amount of hydrogen ( $\mathrm{mmol} / \mathrm{l}$ ) was calculated using ideal gas law; total molaric amount of hydrogen $(\mathrm{mmol} / \mathrm{l})=$ Cumulative hydrogen production $(\mathrm{ml} / \mathrm{l})$ divided by RT. Where, $\mathrm{R}=0.0821 \mathrm{~atm} \mathrm{~K} \mathrm{~mol}^{-1}$ and $\mathrm{T}=303 \mathrm{~K}$.

$H_{(t)}=P . \exp \left\{-\exp \left[\frac{R_{m} \cdot e}{P}(\lambda-t)+1\right]\right\} \ldots .$. Eq. 1

$H(t)$ is the cumulative hydrogen production $(\mathrm{ml} / \mathrm{l}) ; \mathrm{P}$ is the hydrogen production potential $(\mathrm{ml} / \mathrm{l}) ; \mathrm{R}_{\mathrm{m}}$ is the maximum hydrogen production rate $(\mathrm{ml} / \mathrm{h})$; e is 2.71828 ; $\mathrm{J}$ is the lagphase time (h); $\mathrm{t}$ is time (h).

\section{Analysis of keratin biodegradation}

The degradation of feathers was evaluated by the dry weight of the keratinous waste remaining on culture broths during incubation. The culture broths were filtered through pre-weighed Whatmann No.1 filter paper and dried at $60^{\circ} \mathrm{C}$ until constant weight. Results were expressed as percentage of the initial weight (considered as $100 \%$ ) of the respective keratinous waste.

Physical and Chemical Characterization

The fermented broth were analysed for various physical and chemical characteristics such as $\mathrm{pH}$, Oxidation-Reduction Potential (ORP), Volatile Fatty Acids (VFA), Alkalinity, Chemical Oxygen Demand (COD), Biological Oxygen Demand (BOD), protein and reducing sugar by $\mathrm{APHA}^{19}$, Lowry et al., ${ }^{20}$ and Miller method ${ }^{21}$.

\section{RESULTS AND DISCUSSION}

Isolation and identification of Keratin degrading microorganisms

The keratin degrading microorganism was isolated from feather waste disposal area by using minimal medium containing keratin powder as substrate. Three morphologically different bacterial colonies were observed on minimal media containing keratin powder as substrate. The protein utilizing capability of the isolates screened by culturing the organisms on skim milk agar. Based on the morphological observation, the three isolates were named as KHAD1, KHAD2 and KHAD3. The partial sequences of these three keratin degrading microorganisms - 16S rRNA genes were determined. Based on the results of $16 \mathrm{~S}$ rRNA partial gene sequence comparison with existing database in GenBank, the isolated bacterial strains were belonged to the genus Serratia marcescens KHAD1 (MH42-2128), Bacillus subtilis KHAD2 (MH422129) and Pseudomonas aeruginosa KHAD3 (MH422009).

Keratin degradation

In the feather broth medium keratin

Table 1. Feather Broth Medium with Keratin Powder: (Aerobic Degradation)

\begin{tabular}{|c|c|c|c|c|c|c|}
\hline \multirow[b]{2}{*}{$\begin{array}{l}\text { S. } \\
\text { No. }\end{array}$} & \multirow[b]{2}{*}{ Isolates } & \multirow[b]{2}{*}{$\mathrm{pH}$} & \multicolumn{3}{|c|}{ Weight Loss (\%) } & \multirow[b]{2}{*}{$\begin{array}{l}\text { Medium } \\
\text { with } \\
\text { chicken } \\
\text { feather }\end{array}$} \\
\hline & & & $\begin{array}{l}\text { Feather } \\
\text { Broth } \\
\text { Medium } \\
\text { with } \\
\text { Keratin } \\
\text { Powder }\end{array}$ & $\begin{array}{l}\text { Feather } \\
\text { Broth } \\
\text { Medium } \\
\text { with } \\
\text { chicken } \\
\text { feather }\end{array}$ & $\begin{array}{l}\text { Minimal } \\
\text { Minimal } \\
\text { Medium } \\
\text { with } \\
\text { Keratin } \\
\text { Powder }\end{array}$ & \\
\hline 1. & Serratia marcescens KHAD1 & 8 & 28 & - & - & - \\
\hline 2. & Bacillus subtilis KHAD2 & 8 & 32 & - & - & - \\
\hline 3. & Pseudomonas aeruginosa KHAD3 & 8 & 22 & - & - & - \\
\hline 4. & Serratia marcescens KHAD1 & 10 & 69 & 1 & 13 & - \\
\hline 5. & Bacillus subtilis KHAD2 & 10 & 63 & 2 & 11 & - \\
\hline 6. & Pseudomonas aeruginosa KHAD3 & 10 & 58 & 1 & 15 & - \\
\hline 7. & Serratia marcescens KHAD1 & 11 & 87 & 3 & 22 & 3 \\
\hline 8. & Bacillus subtilis KHAD2 & 11 & 82 & 2 & 28 & 5 \\
\hline 9. & Pseudomonas aeruginosa KHAD3 & 11 & 93 & 4 & 33 & 11 \\
\hline
\end{tabular}




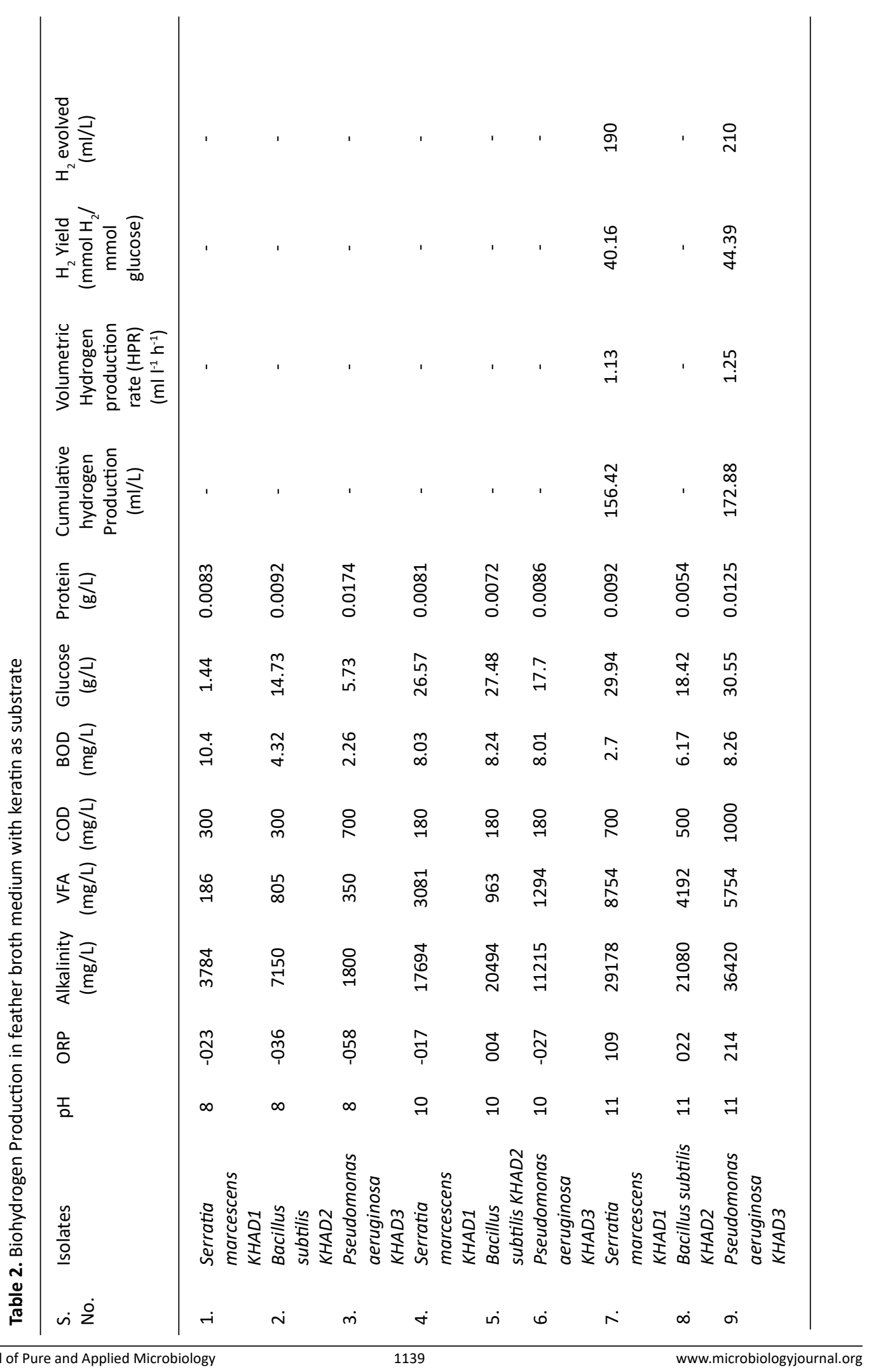




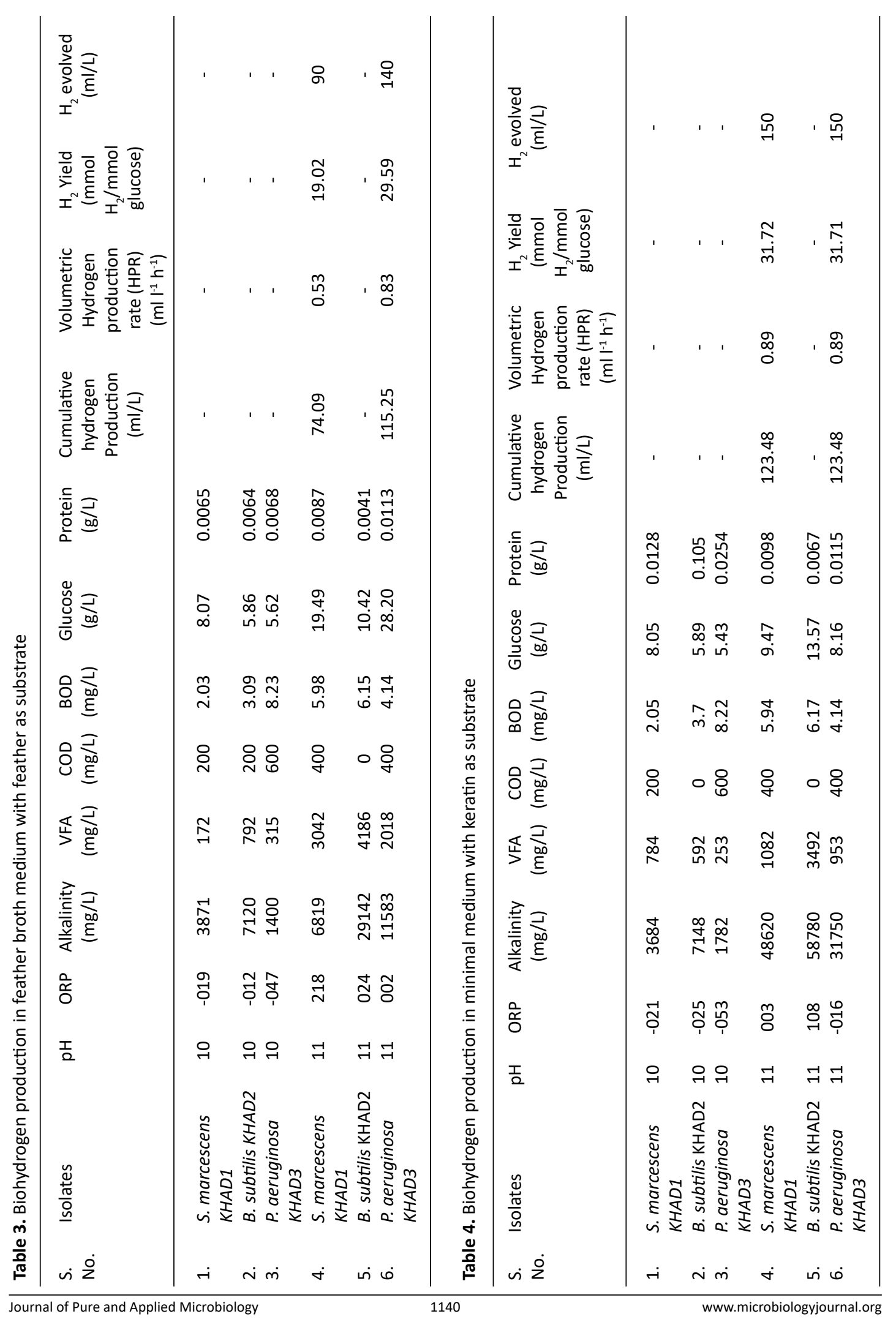


powder as substrate in different $\mathrm{pH}$ condition, the isolates were able to utilize keratin at $\mathrm{pH} 8$, 10 and 11 and unable to utilize the substrate in $\mathrm{pH} \mathrm{1,2,4}$ and 6. Among the three isolates, Pseudomonas aeruginosa KHAD3 shows the higher keratin degradability at $\mathrm{pH} 11$ (93\%). In the feather broth with feather as substrate, the isolates were able to utilize feather as substrate only at $\mathrm{pH}$ 10 and 11 at very less level when comparing it with feather broth medium containing keratin as substrate. In the minimal medium containing keratin powder as substrate, the organisms were able to degrade keratin at PH 8, 10 and 11 with a range of $11 \%$ to $33 \%$. When comparing this result, feather broth medium with keratin powder lesser level of utilization was observed minimal medium containing keratin powder as substrate. In minimal media with feather as substrate, the organisms were able to utilize feather as substrate in higher $\mathrm{pH}$ of 11 with a range of $3 \%$ to $11 \%$. When comparing the keratin utilization in the form of powder or feather, the maximum substrate utilization was seen in feather broth medium with keratin powder at $\mathrm{pH} 11$. In all the cultural conditions, the maximum substrate utilization was seen at $\mathrm{pH}$ 11. This suggested that, the isolates exhibit high range of substrate utilization at $\mathrm{pH} 11$ (Table 1).

In anaerobic cultural condition, there was no significant substrate utilization in all $\mathrm{pH}$ except at $\mathrm{pH} 11$ in the minimal media with keratin powder as substrate- Serratia marcescens KHAD1 (2\%), Bacillus subtilis KHAD2 (8\%), Pseudomonas aeruginosa KHAD3 (3\%).

\section{Biohydrogen}

Biohydrogen production in feather broth medium with keratin powder as substrate at $\mathrm{pH}$ 11 , the maximum of $210 \mathrm{ml} / \mathrm{L}$ medium hydrogen yield was obtained, produced by Pseudomonas aeruginosa KHAD3. At the same $\mathrm{pH}$, the maximum of $190 \mathrm{ml} / \mathrm{L} \mathrm{ml}$ medium hydrogen yield was obtained, by Serratia marcescens KHAD1 (Table 2). In chicken feather as substrate, the feather broth medium produced hydrogen yield at the maximum of $140 \mathrm{ml} / \mathrm{L}$, at $\mathrm{pH} 11$ by Pseudomonas aeruginosa KHAD3 (Table 3). In the minimal medium with keratin as substrate, at $\mathrm{pH} 11$ maximum of 150 $\mathrm{ml} / \mathrm{L}$ medium hydrogen yield was obtained by both the isolates Pseudomonas aeruginosa KHAD3 and Serratia marcescens KHAD1 (Table 4). 
Minimal medium containing feather as substrate, produced maximum of $100 \mathrm{ml} / \mathrm{L}$ hydrogen yield, by Pseudomonas aeruginosa KHAD3 (Table 5). From this experiment, the maximum keratin degradation and biohydrogen production was seen in alkali condition ( $\mathrm{pH} 11)$. Bבlint et al., ${ }^{22}$ also reported the biohydrogen from keratin biowaste at $\mathrm{pH} 8$.

\section{CONCLUSION}

Due to the rapid depletion of fossil fuels, emission of greenhouse gases causing global climate change and increasing oil price, there is an urgent demand for renewable, clean fuel alternatives for our future energy supply. Hydrogen, a regenerative and environmentally friendly fuel with high calorific value has attracted much attention by scientists. The hydrogen economy concept envisions that the future global energy demands will be mainly satisfied by hydrogen fuel instead of fossil fuels. The Hydrogen can be produced through different routes and from various substrates. Biological hydrogen production from a renewable biomass such as the organic fraction of waste or wastewater has considerable potential with respect to solving global environmental issues ${ }^{23}$. Hydrogen energy will be defined as the usable heat or power derived from using hydrogen or a hydrogen rich fuel, as the single fuel source.

Molecular hydrogen derived from renewable sources is a potentially valuable alternative to fossil fuels. Two biological technologies to known to yield maximum rates of hydrogen production are (a) Photoproduction by purple photosynthetic bacteria requiring light energy and simple organic as reductants and (b) dark, fermentative hydrogen production acidogenic bacteria. But, both the methods have drawbacks.

Therefore, alternative method was needed. Concerning about the environmental wastes, feathers are produced in large quantities as a waste byproduct reaching millions of tons every year from poultry farms worldwide. Feathers are rich in keratin protein and due to the cross linking of disulphide bridges, hydrogen bonds and hydrophobic interactrions, the feathers are not degraded by common proteolytic enzymes. Therefore, the feathers were degraded and the degraded effluent was used for biohydrogen production.

\section{ACKNOWLEDGEMENT}

The authors acknowledge the University Science Instrumentation Centre (USIC), Alagappa University, Karaikudi, Tamil Nadu, India for providing instruments facilities.

\section{CONFLICT OF INTEREST}

The authors declares that there is no conflict of interest.

\section{AUTHORS' CONTRIBUTION}

All authors have made substantial, direct and intellectual contribution to the work and approved it for publication.

\section{FUNDING}

This work was financially supported by: 1. Department of Science and Technology-Science and Engineering Research Board (DST-SERB-No.SB/ YS/LS-47/2013), India.

2. Department of Science and TechnologyPromotion of University Research and Scientific Excellence(DST-PURSE) (DST letter No.SR/PURSE phase 2/38(G), dt.21.02.2017), India

3. RUSA - Phase 2.0 grant sanctioned vide Letter No. F.24-51/2014-U, Policy (TNMulti-Gen), Dept. of Edn., Govt. of India, Dt: 09.10.2018.

\section{DATA AVAILABILITY}

All datasets genertated or analyzed during this study are included in the manuscript and the 16s rRNA sequences of Accession No. MH422128, MH422129 and MH422009 are available in NCBINucleotide databases.

\section{ETHICS STATEMENT}

This article does not contain any studies with human participants or animals performed by any of the authors.

\section{REFERENCES}

1. Kapdan I.K., Kargi F., Bio-hydrogen production from waste materials, Enzyme Microb. Technol., 2005; 38: pp. 569-582.

2. Lay J.J., Li Y.Y., Noike T., Mathematical model for methane production from landfill bioreactor, J. Environ. Eng., 1998; 124: pp. 730-736.

3. Lin C.Y., Lay C.H., Carbon/nitrogen-ratio effect 
on fermentative hydrogen production by mixed microflora, Int. J. Hydrogen Energy, 2004; 29: pp. 41-45.

4. Lopes Pinto, F.A., Troshina O., Lindblad P., A brief look at three decades of research on cyano-bacterial hydrogen evolution, Int. J. Hydrogen Energy, 2002; pp. 1209-1215.

5. Fan Y., Li C., Lay J.J., Hou H., Zhang G., Optimization of initial substrate and $\mathrm{pH}$ levels for germination of sporing hydrogen-producing anaerobes in cow dung compost, Bioresour. Technol., 2004; 91: pp. 189-193.

6. Ueno Y., Fukui H., Goto M., Operation of a two-stage fermentation process producing hydrogen and methane from organic waste, Environ. Sci. Technol., 2007; 41: pp. 1413-1419.

7. Kotay S.M., Das D., Biohydrogen as a renewable energy resource - Prospects and potentials, Int. J. Hydrogen Energy, 2008; 33: pp. 258-263.

8. Das D., Veziron T.N., Hydrogen production by biological processes/: a survey of literature, Int. J. Hydrogen Energy, 2001; 26: pp. 13-28.

9. Onifade A.A., Al-Sane N.A., Al-Musallam, A.A., AlZarban S., A review: Potentials for biotechno-logical applications of keratin-degrading micro-organisms and their enzymes for nutritional improvement of feathers and other keratins as livestock feed resources, Bioresour. Technol., 1998; 66: pp. 1-11.

10. Manczinger L., Rozs M., Vבgvylgyi C., Kevei F., Isolation and characterization of a new keratinolytic Bacillus licheniformis strain, World J. Microbiol. Biotechnol., 2003; 19: pp. 35-39.

11. Papadopoulos M.C., El Boushy A.R., Roodbeen A.E., Ketelaars E.H., Effects of processing time and moisture content on amino acid composition and nitrogen characteristics of feather meal, Anim. Feed Sci. Technol., 1986; 14: pp. 279-290.

12. Agrahari S., Wadhwa N., Degradation of chicken feather a poultry waste product by keratinolytic bacteria isolated from dumping site at ghazipur poultry processing plant, Int. J. Poult. Sci., 2010; 9: pp. 482-489.
13. Holt J.G., Krieg N.R., Sneath P.H.A., Staley J.T., Williams S.T. Bergey's manual of determinative bacteriology, $9^{\text {th }}$ ed., Williamsons and Wilkins, Balitomore, 1994.

14. Janardhanan S., Vincent S. Practical Bio-technology, Methods and Protocols. University Press (India) Private Ltd., 2007.

15. Rochelle P.A., Will J.A.K., Fry J.C., Jenkins G.J.S., Parkes R.J., Turley C.M., Weightman A.J. Extraction and Amplification of $16 \mathrm{~S}$ rRNA Genes from Deep Marine Sediments and Seawater to Assess Bacterial Community Diversity. In: Nucleic Acids in the Environment. J.T. Trevors and J.D. van Elsas (Eds) Springer. Berlin, 1995; pp. 219-239.

16. Shawkey M.D., Pillai S.R., Hill G.E., Do featherdegrading bacteria affect sexually selected plumage color?, Naturwissenschaften., 2009; 96, pp. 123-128.

17. Lay J.J., Lee Y.J., Noike T., Feasibility of biological hydrogen production from organic fraction of municipal solid waste, Water Res., 1999; 33: pp. 2579-2586.

18. Chen C.C., Lin C.Y., Lin M.C., Acid-base enrichment enhances anaerobic hydrogen production process. Appl. Microbiol. Biotechnol., 2002; 58; pp. 224-228.

19. APHA. Standard Methods for the Examination of Water and Wastewater. 1995.

20. Lowry O.H. Rosebrough, N.J., Farr, A.L., Randall, R.J., Protein Measurment with the folin phenol reagent. J. Biol. Chemisry., 1951; 193, pp. 265-275.

21. Miller, G.L. Use of dinitrosalicyclic reagent for determination of reducing sugar. Anal. Chem., 1959; 31: 426-428.

22. Bבlint B., Bagi Z., Tףth A., Rבkhely G., Perei K., Kovב cs K.L., Utilization of keratin-containing biowaste to produce biohydrogen, Appl. Microbiol. Biotechnol., 2005; 69: pp. 404-410.

23. Levin D., Biohydrogen production: prospects and limitations to practical application, Int. J. Hydrogen Energy., 2004; 29: pp. 173-185. 